\title{
FREUD NA GALERIA DE AUTÔMATOS DE HOFFMANN: UMA LEITURA A PARTIR DE DAS UNHEIMLICHE DOS MOTIVOS ESTÉTICOS DA PERSONAGEM DO BONECO EM CONTOS DO ESCRITOR ALEMÃO OITOCENTISTA ${ }^{1}$
}

Lucas Henrique Silva (UNESP)

Recebido em 22 jun 2019. Lucas Henrique da Silva é Mestre em Literatura Aprovado em 20 ago 2019. Comparada. Cursa Doutorado em Teoria da Literatura pela UNESP Campus Araraquara. Desenvolve tese sobre E. T. A. Hoffmann. É autor de artigos como "Um mosaico de duplos" (2018) e "Um ventríloquo ilusionista" (2017). Participa do projeto de pesquisa "Literaturas do Eu", sob coordenação da Profa Dra. Karin Volobuef. Tem interesse nos seguintes temas: a personagem artificial na literatura e em outras artes; literatura e psicanálise; E. T. A. Hoffmann; Hans Bellmer; personagem Olímpia. Currículo Lattes: http://buscatextual.cnpq. br/buscatextual/visualizacv.do?id=K4835395T1. E-mail: lukas.henrique15@hotmail.com

Resumo: A partir do texto de Freud de 1919, buscouse analisar os sentidos latentes na personagem do autômato em três textos de Hoffmann: "O homem da areia", "Os autômatos" e "O Quebra-nozes e o Camundongo Rei". Como suporte de trabalho, fezse uso dos estudos de Theodor W. Adorno e Walter unheimliche of the aesthetic motifs of the doll character in short stories of the german 18th century writer". 
Benjamin, junto de outros textos de Freud que abordam a questão do brinquedo e do elemento infantil.

Palavras chave: E. T. A. Hoffmann; "O homem da areia"; Olímpia; Turco; Quebra-nozes; Inquietante.

Abstract: From the 1919's Freud's work, this study analysis the latent meanings in the character of the automata in three texts of Hoffmann: "The Sandman", "The automata" and "The Nutcracker and the mouse king". As a support for the reading, the studies of Theodor W. Adorno and Walter Benjamin were used, along with other texts that Freud deals with the question of the toy and the childish.

Keywords: E. T. A. Hoffmann; "The Sandman"; Olympia; Turk; Nutcracker; Uncanny.

E. T. A. Hoffmann colocou diversas vezes em seus contos personagens autômatos, "O homem da areia" é o primeiro deles, do livro Noturnos, de 1816. Em 1819, aparecem "O Quebra-nozes e o Camundongo Rei" e "Os autômatos", no livro Os Irmãos Serapião. As personagens são, respectivamente: a boneca Olímpia, o soldado Quebra-nozes e o Turco. Além deles Hoffmann inclui em sua ficção uma série de outras figuras da realidade, como as máquinas musicais de Jacques de Vaucasson, famoso inventor francês do século XVIII, por exemplo. O autômato se constitui, assim, como uma verdadeira obsessão criativa do escritor, sugerindo diversas leituras.

Hoffmann é o grande colecionador na literatura de bonecos encantados, autômatos assustadores e outras máquinas. Suas criaturas encontram-se enraizadas no imaginário cultural, variando em recorrências, seja em obras de arte ou estudos. Olímpia é objeto de leitura do ensaio de Freud (2010b) - originalmente escrito, em 1919, com o título "Das Unheimliche", que neste artigo 
será tratado pela edição traduzida "O Inquietante", da Companhia das Letras - que trata dos motivos psicológicos da personagem. Por isso, talvez, Olímpia seja considerada a mais importante das personagens autômatas de Hoffmann, tornando-se paradigma para leitura psicanalítica dos textos do escritor alemão, assim como do próprio conceito freudiano de unheimliche. Olímpia aparece, também, na famosa ópera de Offenbach: Os contos de Hoffmann (1881), obra que ajudou a divulgar Hoffmann para a Europa. Os outros, o Turco e o Quebra-nozes, também não ficam para trás, principalmente o último. Tchaikovsky, em 1891, efetiva uma releitura em balé da história de Hoffmann, por meio de adaptação francesa de Alexandre Dumas, dez anos após a estreia de Offenbach. O autômato Turco, por sua vez, de "Os autômatos", aparece no ensaio "O jogador de xadrez de Maezel" de Edgar Poe em 1836, e, um século depois, no estudo de Walter Benjamin de 1940, "Teses sobre o conceito de História"2.

Olímpia, entretanto, é a personagem de maior plasticidade das três, por trazer, em sua constituição, o projeto de Hoffmann para os autômatos, condensados para o nível de ficção. O elemento infantil do Quebra-nozes aparece nela transtornado para o mundo dos adultos, no qual Olímpia impera como um objeto de interesse equivalente ao melhor brinquedo. Já o caráter sinistro do boneco

2

O Turco constitui uma exceção entre as três personagens pelo fato de ser uma recriação ficcional: o boneco mecânico de Wolfgang von Kempelen, inventor austríaco do século XVIII. O boneco setecentista, que era capaz de disputar partidas de xadrez com pessoas reais, no conto, faz-se distorcido por Hoffmann, dotando-se de capacidades musicais, mantendo, porém, suas características marcantes, como a vestimenta turca, que lhe concede a alcunha. Todas as máquinas de "Os autômatos" são empréstimos diretos da realidade. Além do Turco, temos, também, as máquinas musicais de Vaucasson. A história desses inventores encontra-se na biografia dos autômatos de Mario Losano, História de autômatos. 
Turco e sua maestria nas artes da farsa são apreendidos por Olímpia para a sua própria apresentação, fazendo de Spalanzani um artista e um ventríloquo da manipulação social. Personagem epítome dos temas de Hoffmann, a leitura de Olímpia se ilumina a partir de uma leitura cruzada dos outros dois contos, naquilo que eles fazem dizer sobre o autômato e a arte.

Partimos, neste estudo, da atenção que Freud volta para a personagem de "O homem da areia". O pai da psicanálise analisou os temas de Olímpia, mas vacilou no enigma da figura, deixando as ressalvas para o campo da estética. O projeto de Hoffmann para os seus autômatos aparece ligado profundamente à questão da arte. Nesse sentido, os motivos psicológicos que Freud enxerga no texto, funcionam principalmente como o substrato latente da estética hoffmanniana. O elemento infantil, o retorno do recalcado e a angústia do olhar narcísico, identificados na triste história de Nathanael e do autômato, mostram-se, em análise comparada, como aspectos fundadores da expressão hoffmanniana. Constituem, assim, elementos inconscientes da linguagem artística, que precisam vir à tona para que a crítica se efetive.

A criação formal artística, a técnica e o desejo inventivo do artista romântico são temas apresentados por Hoffmann, mas que pouco significam sem a dialética que fez com que o escritor alemão se destacasse tanto nos estudos estéticos quanto nos psicológicos. Esses temas, Hoffmann captava de sua realidade social. Ao observar em sua época o interesse crescente pela técnica artística destituída de qualquer subjetividade, sua preocupação era a de que o homem, consumido pelo desejo de inventar cada vez mais instrumentos reprodutores da arte, acabasse alienado pelo seu próprio objeto. 
Assim, compara o autômato ao brinquedo infantil, como um objeto impostor que desperta o interesse do artista para capturá-lo na sua sensualidade de dominar o indomável: a natureza, identificada como o próprio espírito artístico. Essas ideias são expressas em formas de histórias terríveis, em que o autômato aparece como um objeto demoníaco e tolo, como se pode notar em "Os autômatos":

As tentativas de criar sons da natureza são realmente maravilhosas e dignas da maior atenção, mas parece-me que até agora o que se fez foi apenas colocar à disposição da natureza um brinquedo insignificante, que ela quebrou em vários pedações sob cólera justa (HOFFMANN, 1993, p.108)

Veremos neste estudo como o tema dos autômatos apresenta uma possibilidade de leitura baseada na dialética do inconsciente e do conteúdo formal, partindo do impulso de Freud (2010b) em 0 inquietante. Refletir sobre a obra de um escritor como Hoffmann, requer, ao mesmo tempo, um olhar para o objeto de arte em relação com aquilo que ela tem de cifrado, de inconsciente, portanto, a Teoria Estética de Theodor W. Adorno (1970) parece o suporte de trabalho mais adequado, devido ao destaque que o estudioso da Escola de Frankfurt traz para o conteúdo latente da criação artística. Além de Adorno, não podemos deixar de lado Walter Benjamin (1984), não somente pelo mesmo motivo, mas, sobretudo, pelo que o filósofo tem a dizer sobre o brinquedo. Benjamin é um dos únicos a pensar as bonecas e os objetos da realidade da criança dentro do trabalho do artista e sua relação com o mundo infantil. Todos esses caminhos são indicados, como veremos, dentro do próprio texto freudiano. 


\section{TRÊS AUTÔMATOS DE HOFFMANN}

Da mesma forma que Marie se apaixona pelo seu boneco quebra-nozes, no conto de gênero maravilhoso, Ferdinando de "Os autômatos" e Nathanael de "O Homem da Areia", são capturados pela atração do autômato: este último por Olímpia, o outro, pelo boneco Turco, figura que na história é ligada misteriosamente a uma cantora desconhecida, personificação da própria arte musical. Entretanto, a crença na animação do boneco, em "O Quebra-nozes", se enquadra no que Freud chama de elemento infantil, predominante nas fábulas e também nos processos animistas, próximo à ênfase da realidade psíquica da criança. Portanto, não se configura como um exemplo inquietante, nem para o leitor. Para que o inquietante aconteça, fazse necessário uma situação de inadequação desse elemento, em que crenças abandonadas na história primária do sujeito ou superstições superadas no processo de racionalização são, de repente, confirmadas pela realidade. Freud identifica, assim, infância e desenvolvimento do sujeito, bem como infância e história da humanidade, atentando para o fato de que certos conteúdos não são verdadeiramente superados, mas reprimidos pelos processos psíquicos. Dessa forma, coloca em questão a própria noção positiva de desenvolvimento, mostrando que o processo de sujeição acontece de forma complexa, baseado em movimentos de recalque, violentos, tanto no sentido individual, quanto no sentido coletivo, como no caso do inquietante e do animismo.

Isso permite que se possa ver, no caso de Nathanael, que acredita que a boneca Olímpia está viva, uma representação de complexos infantis, que retornam e tomam o aspecto inquietante. Mesmo desejos infantis, para Freud, podem se tornar motivo de 
angústia quando realizados na vida adulta, por isso, para ele, há neste caso o elemento infantil. No caso de Nathanael, trata-se do retorno do complexo da castração, no qual a boneca aparece como elemento apaziguador. Nathanael vê na figura do Homem da Areia a ameaça da castração, ligada a eventos traumáticos de sua infância e, portanto, abjetada logo cedo. Assim, o Homem da Areia é substituído pelo "pai temido, de cujas mãos se espera que venha a castração" (FREUD, 2010b, p.348). Nathanael realiza o seu desejo, tomando Olímpia como objeto, protegendo-se da ameaça da castração que o persegue na figura do Homem da Areia. Olímpia se torna, então: "a materialização da postura feminina de Nathanael ante seu pai na primeira infância" (FREUD, 2010b, p.348). Essa cisão que o Eu opera por meio de processos inconscientes, para Freud, visa desviar a castração, adiando tanto a satisfação quanto a realidade, estrutura na qual podemos localizar o caráter fetichista de Nathanael.

Como geralmente se dá com o fetichista, Nathanael é incapaz de amar, pois está condicionado a refazer sempre a situação de satisfação que faz com que se negue a castração. Freud afirma que esta impossibilidade, em Nathanael, se dá pela sua fixação no pai, em decorrência do traumático processo de castração. O fetiche está ligado a uma dupla percepção da realidade, em que o sujeito, ao perceber a castração, opera uma ambiguidade na realidade, aceitando-a e recusando-a ao mesmo tempo. Olímpia, portanto, para Nathanael - e para o leitor, segundo Freud (p.356), que acredita que Hoffmann quer fazer com que "nós mesmos olhemos através dos óculos ou binóculos do demoníaco ótico" - está ligada à percepção, o que explica sua relação com os temas do olhar, tornando-se reflexo da realidade psíquica e da formação de Nathanael. 
Em "Os autômatos", podemos levar adiante a leitura freudiana. A dúvida de Ferdinando sobre a natureza do boneco Turco encontra resquício na sua vida infantil. Aqui, ao invés do medo de perder o olho, como em "O homem da areia", apresentam-se outros elementos narcísicos, como a voz, a imagem etc. O Turco se torna, para Ferdinando, espécie de projeção de sua cisão psíquica. A sua voz, sinistra e mecânica, lembra um chamado sinistro, interior ao próprio Eu. Na história, o Turco mostra conhecer o segredo de Ferdinando: o amor pela cantora misteriosa, pintada em um retrato no seu peito. Ele o humilha, em tom incomum para um simples boneco: "ao me aproximar do Turco, perguntei, pensando na amada de meu coração: 'ainda terei no futuro um momento igual ao mais feliz da minha vida?"', conta ao seu amigo Ludwig, "O Turco, como você terá notado, não queria responder; como eu insistisse, finalmente disse: 'Meus olhos contemplam teu peito, mas o brilho do ouro que está voltado para mim confunde minha visão. Vire o retrato!"' (HOFFMANN, 1993, p.95).

Fica claro, nesse registro comum à história, a recorrência do complexo de castração em torno da figura do boneco, desta vez em toda a sua potência de imagem paterna, por meio de um autômato masculino, ao invés da reconfortante figura materna que ganha forma na boneca Olímpia. No final de "Os autômatos", quem dá a última palavra é, também, a imagem paterna: o próprio pai de Ferdinando o convoca, interrompendo a história. Como obstáculo ao seu amor pela cantora misteriosa, além do Turco, Ferdinando se depara com o Professor $X$, um criador de autômatos, figura extravagante e misteriosa, combinando os conteúdos de Spalanzani e Coppola. No final da história, o Professor X se revela ligado à misteriosa figura feminina sonhada por Ferdinando, como 
se ela fosse uma de suas filhas. Temos, portanto, a repetição da situação em que a figura masculina está ligada tanto com a criação do objeto de desejo do protagonista quanto com sua destruição. Freud enxerga na tematização de complexos paternos reflexos da biografia de Hoffmann (FREUD, 2010).

Marie, por sua vez, está ligada às duas figuras de ordem paterna: seu pai, que lhe passa a tarefa de cuidar do boneco quebra-nozes, e o seu padrinho, Drosselmeyer, criador do boneco, figura esquisita, surreal, que durante à noite aparece em imagens oníricas e fabulosas para a criança. Marie se apega ao seu quebra-nozes a partir do evento do acidente que causa danos ao brinquedo, em decorrência da insistência do seu irmão tirano Fritz em fazer o boneco esmagar nozes grandes e duras. Era, afinal, tanto um presente quanto uma incumbência de seu pai e do seu padrinho: "se você gosta mesmo do amigo QuebraNozes, querida Marie", eis o conselho do pai, "você é que vai guardá-lo e protegê-lo bem" (HOFFMANN, 2017b, p.197). O boneco quebra-nozes é, para Marie, um elo com a sua história desconhecida, por meio do conflito de gerações, representando sua curiosidade pelo pai e pelo padrinho: "o pequeno e elegante homenzinho provinha dos povos quebradores de nozes e desempenhava a profissão de seus antepassados", descobre, interessada pela estranha similaridade que via entre a vestimenta cômica do boneco e a do padrinho. Assim, a menina se projeta, de certa forma, no seu boneco. Temos aqui elementos fálicos, objetos de ligação para a criança: os dentes do boneco quebranozes, o presente do pai, que se instalam no conflito edipiano com o irmão tirano. 
O boneco quebra-nozes não é do mesmo tipo de artefatos de Olímpia e Turco, por isso, talvez, ele seja encantado em Hoffmann, figura positiva, enquanto o autômato é funesto e diabólico. Temos em "O Quebra-nozes" a angústia, todavia, como parte da história necessária para o crescimento de Marie, distante do reino do inquietante. $O$ boneco quebra-nozes de Marie representa a pureza dos brinquedos do passado, por isso, vai ser renegado pela nova geração, representada pelo irmão, que reclama da inutilidade do brinquedo: "escute, padrinho, se as pequenas figuras enfeitadas do seu castelo não podem fazer outra coisa além disso, então elas não servem para nada e não me interessam" (HOFFMANN, 2017b, p.195). Entretanto, para encerrar aqui, podemos destacar no conto a recorrência da relação paterna. A ligação da criança com o mundo dos adultos por meio de seu brinquedo se situa nesse limiar.

\section{UMA CRIANÇA E DOIS ARTISTAS}

O que mais se destaca na comparação das três histórias é uma pequena diferença. Trata-se do fato de que, a partir de Nathanael e Ferdinando, temos, ao invés da personagem infantil, a do artista romântico; as duas classes apresentam estranha equivalência. As personagens hoffmannianas, sobretudo as da classe dos artistas, são, muitas vezes, figuras infantis, destacadas do mundo prosaico pela sua imaginação, como sujeitos criativos e curiosos (VOLOBUEF, 1999). Entretanto, no caso das personagens dos contos do autômato, o elemento infantil se impõe como uma inadequação, inaugurando o inquietante. $\mathrm{O}$ autômato se apresenta para o artista como o brinquedo para a criança. Sua sensualidade 
é oblíqua, sem vida, bem diferente da representação das crianças na brincadeira, tema que acompanharemos, neste estudo, com Walter Benjamin.

O que leva estas personagens artistas a desenvolverem uma relação com o autômato, se analisado de perto, não é muito distante do motivo das crianças, que Freud relaciona ao primeiro narcisismo, lugar em que o $E u$ ainda não difere muito bem os seus limites. Os brinquedos, nesse momento, apresentam-se como objetos de ligação com a realidade, prontos para serem transformados pela brincadeira. Se o autômato e o brinquedo são estes objetos, no caso dos adultos, não há espaço para a criação infantil. A relação de Marie com o seu boneco, que faz com que a criança supere o trauma de ordem paterna, não é mais possível para Nathanael e Ferdinando. Voltaremos a isso.

A história das personagens artistas compõe-se, não por acaso, por segredos, eventos traumáticos e conflitos. Para lembrar a afirmação de Freud sobre a incapacidade do amor em Nathanael, estes conflitos são tanto amorosos quanto artísticos, ao mesmo tempo. Ferdinando com a cantora misteriosa, Nathanael, por sua vez, com Clara, sua namorada humana. Este último, pouco antes de conhecer Olímpia, encontrava-se em processo de criação de um poema diabólico, do qual não sabemos muito, além da reação negativa de Clara, entre o pavor e o tédio. Nathanael parece abandonar as criações quando conhece a sua amada que, para ele, equivale à própria noção de beleza e de sublime personificada. Antes, porém, dedicava-se a uma criação de alta qualidade formal. Hoffmann destaca a musicalidade e a composição organizada do artista. Ao finalizar a criação, em um momento, Nathanael 
parece desconhecê-la, reagindo como que assomado por outra voz desconhecida. Sua atitude faz lembrar a reação do público ao canto estridente e mecânico de Olímpia, algumas cenas depois. Eis o trecho da primeira cena:

Concentradamente Nathanael se entretinha em sua composição. Retocava e aprimorava com calma as passagens e, como as submetera à métrica das estrofes, não descansou enquanto não obteve a musicalidade e a pureza almejadas. Apesar disso, não se mostrou satisfeito quando finalmente concluiu e leu tudo em voz alta para si mesmo, se perguntando exasperado: - De quem é essa voz pavorosa? Em questão de segundos, porém, estava novamente convencido do primor do poema, e considerou que com ele acenderia o coração frio de Clara. Mas não refletiu claramente sobre o que acenderia no coração da amada ou o que sobreviria assim que a impressionasse com as imagens horríveis, presságios de ruína e destruição de seu amor (HOFFMANN, 2017a, p.97, grifo nosso)

A principal crítica ao canto de Olímpia resume-se ao fato de que toda a sua precisão e formalidade dava a impressão de uma música sem vida, por mais bela que fosse, assim como se dava com a sua aparência: "todos os seus movimentos acontecem como se condicionados pelo impulso de um mecanismo de corda", diz Sigismundo, "sua maneira de tocar, cantar, possui uma desagradável precisão rítmica das caixas de música [...], essa Olímpia nos causou uma impressão bastante sinistra" (HOFFMANN, 2017a, p.107-108). Nathanael equivale o mutismo de Olímpia ao reino divino, superior, para além das palavras: "mas o que são palavras, meras palavras! O olhar de seus olhos celestiais expressa 
bem mais que qualquer outra linguagem terrena!". Aqui, podemos entender um pouco melhor a relação de Olímpia com a arte, pois a linguagem artística sem palavras é, justamente, a música, não por acaso a arte mais pura para o romantismo (VOLOBUEF, 1999). Olímpia seria então, para Nathanael, a personificação da beleza, manifestação do espírito sublime da natureza, do mundo sensível. Sua ligação é mais direta com a música, mas representa o próprio estatuto da arte.

Logo em seguida, o poeta enamorado, ainda, identifica arte sublime e universo infantil, vendo, distorcidamente, na imagem de sua amada a figura da criança arte, tão buscada na criação da beleza poética: "seria pois possível a uma criança dos céus resignar-se a um círculo estreito mais limitado de nossa lamentável existência terrena?" (HOFFMANN, 2017a, p.109). Fica claro que Olímpia, de porte regular e traços perfeitamente organizados, representava tudo aquilo que Nathanael buscava, como uma substituição da obra de arte, como se o poeta tivesse, enfim, encontrado o que buscava durante toda a vida. Depois de ouvir o canto de Olímpia, Nathanael esquece toda a sua produção artística anterior. Em ocasião de um dos encontros com a amada, procurando algum pretexto, encontrava-se desesperado por qualquer coisa que pudesse aproveitar para as longas horas que passava em companhia de Olímpia em seu quarto. As antigas produções aparecem como um amontoado de coisas acumuladas: "do fundo de suas gavetas do escritório, Nathanael extraía tudo o que um dia escrevera. Poemas, caprichos, novelas, sonhos, romances, e isso se multiplicava a cada dia com todo o gênero de sonetos delirantes, estâncias, baladas fantásticas" (HOFFMANN, 2017a, p.109). 
Em "Os autômatos", como era de se esperar, temos a repetição destes motivos, agora sob um registro mais próximo do ensaio e do debate, dado o alto teor filosófico da história de 1819. Ferdinando e Ludwig, os dois protagonistas, são sujeitos sensíveis em artes musicais, sendo a segunda personagem, claramente, uma homenagem a Ludwig van Beethoven ${ }^{3}$, músico contemporâneo ao escritor, que exerceu grande entusiasmo no Hoffmann crítico musical. No conto, Ludwig é amigo fiel de Ferdinando, como um guia sábio e sensível, cujos esforços para tirar o artista das forças do autômato é um compromisso com a própria arte. É Ferdinando quem mais se aproxima de Nathanael, representando, no conto, o artista romântico. Os charlatães perigosos ameaçam o seu amor pela cantora misteriosa. A relação de seu objeto de busca com o Turco é altamente perturbadora. Quando Ferdinando descobre as relações entre a cantora e o Professor $\mathrm{X}$, execrável criador das máquinas sinistras, tudo lhe parece perdido, cumprindo assim a profecia do Turco: "Infeliz! No momento em que a vires novamente, ela estará perdida para ti!” (HOFFMANN, 1993, p.95).

A cantora misteriosa do conto é, podemos dizer, a própria personificação da música, por isso sua imagem é sempre um devaneio fabuloso, impossível de ser capturado em uma imagem. O que a Ferdinando resta fazer, depois de ouvi-la cantar em sonho, é pintála. A metáfora se completa pelo fato de que, em música, muito dos vocábulos usados para se categorizar o som são justamente oriundos da pintura. Assim, Ferdinando tenta captar em uma imagem aquilo que experenciou em som, a fim de eternizar o incapturável. É neste ponto que entendemos melhor o autômato como uma máquina 
sinistra musical. A ideia de reproduzir a música nessas máquinas é uma mutilação, pois mata aquilo que a música tem de arte, isso é, emanação do superior, do desconhecido, que só pode se dar pelo espírito. No conto temos, diversas vezes, alusões a essa relação. Voltaremos a isso.

Em "Os autômatos", as máquinas são vistas muitas vezes como verdadeiros brinquedos criados pela técnica para se alcançar efeitos artísticos. Como brinquedo, ele não pode conter a natureza indomável, sendo fadado ao fracasso: "as tentativas de criar sons da natureza são realmente maravilhosas e dignas da maior atenção, mas parece-me que até agora o que se fez foi apenas colocar à disposição da natureza um brinquedo insignificante, que ela quebrou em vários pedações sob cólera justa” (HOFFMANN, 1993, p.108). Assim, Hoffmann cria uma história em que estes brinquedos se tornam o perigo, em mãos de sujeitos perigosos, como o Professor $X$, a fim de se apropriar da arte musical e fazê-la se perder para sempre nas mãos da técnica. Não podemos esquecer que, no final de "O homem da areia", Spalanzani tem que fugir da cidade, sob risco de prisão, culpado de farsa e escândalo. Na cena final de "Os autômatos", há uma passagem em que Ludwig se pergunta se o Professor $X$ não manipulou uma ilusão coletiva com suas máquinas musicais, por meio do som vibratório, copiado da música das esferas. Aqui, o que se tematiza é a alienação do objeto artístico, nas mãos do perigoso pensamento tecnicista.

Podemos visualizar, nessas questões, o compromisso romântico de Hoffmann para com a arte, a fim de livrá-la do fetichismo técnico ${ }^{4}$. Adorno (1970) vai chamar esta ameaça de fetichismo da

40 romantismo alemão identificou natureza com princípio criativo, localizando-a na potência criativa do próprio sujeito, naquilo que ele tem de desconhecido (VOLOBUEF, 1999). O argumento antirromântico da arte enquanto 
técnica, apontando o perigo da alienação em que a arte focada no objeto artístico e no estudo formal dos elementos, sobretudo a música, ocorre. Nesse sentido, tanto Adorno quanto Hoffmann invocam o reino perdido da infância como única saída para esta tendência tecnicista, própria dos adultos alienados. Adorno, leitor de Freud, traz esta questão para a própria história do sujeito, na imagem da criança ao piano: "a relação ao Novo tem o seu modelo na criança que busca no piano um acorde jamais ouvido, ainda virgem. Mas, o acorde já existia desde sempre" (ADORNO, 1970, p.45). A aproximação da criação artística ao mundo infantil, em Adorno, tem como objetivo fazer oposição o fetiche da técnica.

Hoffmann, lido por Freud, fez com que o artista lembrasse a criança curiosa (VOLOBUEF, 1999), aproximando a criação à imersão infantil na fantasia, como o mundo dos brinquedos para onde Marie é levada pelo seu quebra-nozes. "Os autômatos", porém, leva esse debate a um nível dialético, em que os perigos da fantasia estão para ser captados pela ameaça tecnocrata. A técnica em função de captar os sons da natureza para fins reprodutivos, como as máquinas musicais, corrompe a arte naquilo que ela tem de mais humano, colocando a expressão da natureza, de caráter inefável, em função de uma sedução deturpada, por meio desses brinquedos. O aspecto grotesco do autômato está localizado nesse caráter perverso, entre ingenuidade e sedução, dos objetos

simples fruto do estudo de seus objetos técnicos voltava-se contra uma mística do espírito subjetivo, identificada em românticos como Richard Wagner, por exemplo. Adorno, fazendo uso da teoria freudiana, vai resolver esta questão, criticando a arte tecnicista, que negava o sujeito artista, mas sem recair para o lado oposto, ao inaugurar a ideia de uma beleza do inconsciente. Hoffmann encontra-se no momento de desenvolvimento desta aporia, e seus autômatos, de certa forma, instauram-se no início da ameaça da música robótica, identificada por Adorno. 
da técnica alienadora. Assim, o artista, ao invés de crescer subjetivamente pelo contato com a natureza, se infantiliza, sujeito à sedução dos brinquedos artísticos.

Nessa aproximação, o escritor oitocentista visualizou o que apontaria Walter Benjamin um século depois sobre o brinquedo. Para Benjamin, o brinquedo tem sua origem menos nas necessidades infantis do que nas adultas - "não são os adultos que dão em primeiro lugar os brinquedos às crianças?" (BENJAMIN, 1984, p. 250), questiona. Benjamin coloca o brinquedo como um objeto entre as gerações, imposto pelo adulto à criança e o seu mundo, marcado pelos vestígios das gerações passadas. A criança, porém, vai apropriá-lo, por meio de seu verdadeiro movimento imaginativo: a brincadeira, que na palavra alemã Spielen quer dizer tanto brincar quanto representar: "a essência da representação, como da brincadeira, não é 'fazer como se', mas 'fazer sempre de novo'" (BENJAMIN, 1984, p.253). Nesse sentido, Benjamin enxerga na brincadeira um jogo devastador de repetição e assimilação de experiências, fazendo lembrar a pequena Marie com o seu quebra-nozes. Hoffmann transpõe a estrutura da brincadeira de Marie, quase que exatamente, para as suas personagens adultas, Nathanael e Ludwig, mas para apresentá-las como uma impossibilidade, para as personagens e para o artista em si. Em todo o caso, o que temos, porém, é a repetição, mas só no caso dos artistas ela recai no terrível unheimlich.

\section{A PERVERSÃO DOS BRINQUEDOS E A REPETIÇÃO}

A fim de aprofundar as questões relacionadas à arte, objeto artístico e brinquedo, passa-se, agora, à questão da inadequação do elemento infantil no universo artístico em Hoffmann. O mundo 
dos brinquedos se faz presente em "Os autômatos" em vários momentos, reforçando a comunicação dos autômatos com os brinquedos infantis. Quase todas as personagens relatam conhecer os famosos museus de cera, as galerias de bonecos mecânicos, orquestras de música artificial, entre outras apresentações comuns na Europa da época. O próprio Hoffmann relata ter assistido à peça do tipo em seus diários, alegando ter sentido um grande desconforto em presença daquela música sem vida, como nos informa Oscar Cesarotto (1987). Certamente, o fato fundamenta a história de "Os autômatos", em que se retrata o mesmo tipo de angústia, gerada por um sentimento estético. O tom desagradável da música mecânica, Hoffmann combina com o elemento insólito, horrífico, buscando uma representação estética ficcional.

Assim, é buscando referência na realidade que Hoffmann abre espaço para os autômatos famosos que inclui em sua história. Além dos autômatos reais, há menção também àqueles de sua ficção, no caso, o boneco Quebra-nozes, conectando explicitamente as duas histórias de Os Irmãos Serapião. Eis o trecho:

"Devo confessar", continuou Ludwig, "que a figura, logo que entrei, lembrou-me nitidamente um belíssimo quebra-nozes que, quando eu era criança, ganhara de um primo de Natal. O homenzinho representado pelo quebra-nozes apresentava um semblante de gravidade cômica, e, quando devia quebrar uma noz muito dura, girava, cada vez, graças a um mecanismo interior, enormes olhos que Ihe saltavam da cabeça; isso proporcionava ao objeto algo de tão vivo e burlesco que eu podia brincar horas a fio com ele, que se tornava em minhas mãos uma verdadeira mandrágora (HOFFMANN, 1993, p.96). 
Além desta, são várias as passagens em que se narram encontros com brinquedos prodigiosos, alguns deles inquietantes, como as bonecas de cera e as dançarinas de madeira, outras, cômicas e ridículas, em que bonecos de toda a sorte são expostos em galerias como verdadeiras obras de arte embusteiras. A memória de Ludwig é, em comparação a estes eventos, um registro positivo, em que se expressa uma relação criativa entre a criança e o seu brinquedo, bem diferente daquela que se passa com o boneco Turco. Ao adentrarem no recinto onde se localizava o artista e o seu artefato, as personagens relatam sentir padrões vibratórios musicais ressoando no ambiente, como se tivessem adentrado um universo estranho e desconhecido, mas estranhamente familiar, em que Ferdinando identifica a música ouvida no fatídico dia de seu encontro com a cantora misteriosa, quando presenciou a sua música inebriante. Essas e outras relações misteriosas do conto estabelecem na narrativa um verdadeiro mosaico de percepções, diferentemente de "O homem da areia", em que temos, como ponto de focalização, a luneta de Nathanael (FREUD, 2010).

Pela comparação entre os autômatos e os brinquedos infantis de outrora, pode-se dizer que à medida que estes objetos ganham em fidelidade de reprodução, seja da imagem humana, seja das capacidades artísticas, tornam-se mais inquietantes, e, no caso dos brinquedos, deixam menos espaço para a imaginação infantil, para lembrar a queixa de Fritz sobre a monotonia dos brinquedos encantados do padrinho. O boneco quebra-nozes, burlesco e vivo como nenhum outro, não expressa a aura repressiva dos autômatos realistas, mas desperta um curioso interesse. A forma racional se torna, nos autômatos, a face de sua própria irracionalidade, fazendo 
lembrar a obra de arte para Adorno (1970). Para o estudioso, a arte carrega em si o burlesco, o desvario, mesmo que para camuflá-lo, pois é nele que se encontra o seu conteúdo mimético: "a divergência do construtivo e do mimético, a que nenhuma obra se acomoda, tem o seu correlato no elemento do desvario e do burlesco, que mesmo as mais importantes obras contêm em si, parte do significado que possuem consiste em camuflá-lo" (ADORNO, 1970, p.139).

A obra que se quer racional, sem fazer dessa racionalidade espírito, é, paradoxalmente, a mais disparatada segundo o critério de razão na realidade. O que explica o motivo da abjeção dos autômatos, em toda a sua racionalidade formal, pelo espírito sensível. É neste sentido que Adorno afirma que o burguês filisteu tem algo contra esse desvario artístico, identificado com o momento mimético, verdadeiro, da arte. Isso porque, para o burguês, é insuportável o que é não-idêntico a si mesmo. Assim, à semelhança que Marie observa entre o quebra-nozes e o seu padrinho, cheia de criatividade, para o tipo filisteu, do qual fala Adorno, é preferível a semelhança com o autômato. O autômato é a epítome do objeto capaz de proporcionar a experiência artística sem ser por ela questionado, fazendo uso dos últimos avanços da técnica.

Dos bonecos quebra-nozes para o Turco, temos, em Hoffmann, uma mudança no estatuto do brinquedo. O Turco ainda lembra os bonecos da infância, o que inspira as gozações de Ludwig, mas vai se mostrar como um objeto corrompido, para uma outra finalidade do que os objetos a ele semelhantes. Tanto que, na história, muito se conta sobre uma transformação pela qual o Turco teria passado, de que teria chegado à cidade primeiramente como um mero objeto de ventríloquo de espírito, até cair nas mãos do Professor X. Conta- 
se que, nesse período, a apresentação permaneceu suspensa, e, ao retornar, o Turco já era esse outro que agora se apresenta sob as mãos do misterioso artista - personagem do ventríloquo que comanda os movimentos do Turco. Na transformação do Turco, Hoffmann tematiza a do próprio brinquedo e, em certo nível, a do próprio objeto de arte, na medida que este se torna indistinguível dos brinquedos infantis menos espirituosos. Podemos afirmar, também, que no horizonte dessa transformação, encontra-se a nossa "boneca freudiana", Olímpia, apresentada para a sociedade como obra de arte, mulher de verdade, mas também como boneca.

Olímpia representa, assim, a completa perversão dos objetos no mundo dos adultos. Em Freud, a perversão se baseia na ideia de que a sexualidade infantil não tem um fim, mas é dinâmica e polimorfa, exploratória. A perversão sexual se encontra plena nas brincadeiras das crianças com o seu brinquedo. O mundo da sexualidade infantil é debatido por Freud em seu ensaio de 1905, no qual afirma: "é instrutivo que a criança, sob influência da sedução, possa tornarse perversa polimorfa e ser induzida a todas as transgressões possíveis" (FREUD, 1996, p.180). A perversão na qual se toca, aqui, é a de que as coisas e os objetos não simplesmente perderam o seu fim, mas passaram a encerrar a própria finalidade em si mesmos, trocando os fins pelos meios. É este o fetichismo da técnica de que fala Adorno (1970).

Ao invés do gozo infantil, de uma perversidade transgressora, implica, agora, no caso sujeito perverso, a negação, como o fetichista que vive de refazer a situação da castração. O fetichismo é o mecanismo pelo qual se nega a castração, sem excluí-la simultaneamente, fazendo com que o sujeito se fixe nesta estrutura 
ambígua. Recai, assim, em uma cisão. Freud visualiza estas questões já em Nathanael, em seu ensaio, quando analisa a extrapolação que o garoto faz das imagens. A questão do fetichismo vai ser sedimentada em ensaio de 1927, de título "O fetichismo". Adorno, por sua vez, vai buscar em Freud e em Marx o conceito para localizálo na experiência estética.

O autômato moderno em Hoffmann, enquanto figura substitutiva da potência criativa do brinquedo e do fazer subjetivo da arte, está mais para o perverso do que para a perversão infantil. Em seu projeto para os autômatos, porém, essa questão é complexificada, a ponto de se tornar quase inconsciente à forma e à linguagem, enchendo-se de sentidos latentes. Como Olímpia substitui o amor para o Nathanael fetichista, o autômato substitui a arte na sociedade. A tecnocracia é, assim, para o artista, como o adulto que impõe brinquedos à criança, lembrando as palavras de Benjamin (1984). Por se tratar de uma inadequação, o artista, em Hoffmann, não pode mais redimir o objeto pela brincadeira, isto é, pelo fazer artístico. Torna-se alienado, rumo a um destino fatal, como Nathanael, que acaba morto na história, e Ferdinando, ambas personagens que recaem em fins trágicos. Esses artistas, sujeitos infantilizados, não por acaso, são aconselhados por sujeitos sensatos, de espírito aguçado, como é o caso de Ludwig, amigo de Ferdinando, um possível caso de epítome de Ludwig van Beethoven.

"O inquietante", como se sabe, situa-se em um momento de divisão das ideias de Freud, apontando tanto para os conteúdos totêmicos dos trabalhos anteriores, com a questão do animismo, por exemplo, como para o desenvolvimento da pulsão de morte 
e da compulsão à repetição, a próxima guinada do pensamento psicanalítico. Podemos visualizar este registro introdutório em apontamentos como o seguinte: "como o efeito inquietante do retorno do mesmo pode remontar à vida psíquica infantil é alto que posso apenas mencionar aqui, indicando para isso uma exposição detalhada, já pronta, realizada em outro contexto" (FREUD, 2010, p.356). Freud se refere, aqui, à obra de 1920, Além do princípio do prazer. O texto que se desenvolve de "Das unheimliche", com certeza, nos ajuda a iluminar as questões do brinquedo e da repetição, justamente se pensarmos que ele se encontra, também, nas reflexões de Walter Benjamin no texto de 1928 aqui mencionado, "Brinquedo e brincadeira". Para Freud, a repetição que no adulto pode ser inquietante é, na criança, meio de se obter a satisfação daquilo que Benjamin chama de "experiência devastadora".

\section{EXPERÊNCIA DEVASTADORA, REPETIÇÃO E ANGÚSTIA}

Em Além do princípio do prazer, Freud analisa, por meio do comportamento da criança com o seu brinquedo, os instintos de conservação do Eu, que impelem o sujeito a agir sobre a realidade. Assim, atualiza a ideia de que os instintos estariam ligados a um processo de desenvolvimento positivo, pois a tendência à repetição revela que, o que importa, originariamente, é a restauração de uma condição anterior. Assim, segundo ele: "um instinto seria um impulso, presente em todo organismo vivo, tendente à restauração de um estado anterior" (FREUD, 2010b, p.202, grifos do autor). Conclui, então, que para além da busca pela satisfação, o instinto obedece ainda a uma lei anterior, a da repetição. 
Freud formula sua hipótese baseando-se, sobretudo, em estudos do jogo infantil. Observando a brincadeira da criança em lançar o seu carretel, só para puxá-lo e vê-lo reaparecer, Freud vê uma encenação de uma situação real: o trauma da ausência da mãe. Disto, compreende que a imitação é um mecanismo da compulsão à repetição, a fim de restaurar uma situação anterior. $\mathrm{Na}$ imitação, tanto o prazer quanto a dor constituem-se como partes de uma mesma finalidade. O desaparecimento do carretel pelas mãos da criança, seguido do seu retorno, gerava uma situação em que sentimentos opostos desembocavam em um fim comum, isto é, a satisfação. Isso porque a criança refazia a alegria do retorno da mãe, depois do trauma de sua ausência. Nesse movimento, a criança passava de um papel passivo frente à realidade para um ativo, fazendo com que o seu desenvolvimento passe por um processo de retorno primordial.

Nas crianças, a "compulsão à repetição e direta satisfação prazerosa do instinto parecem aí entrelaçadas em íntima comunhão" (FREUD, 2010, p.183), o que se complexifica, certamente, no adulto. Dentre as experiências de imitação por parte do sujeito, em sua teoria, Freud relaciona jogo e arte. Por arte, entende-se os jogos artísticos, no caso, anterior ao conceito de arte como ele se funda na sociedade ocidental. Contudo, o que interessa a Freud, sobretudo, é a ideia de fruição, comum ao fazer artístico e ao jogo. Isto porque, nestas atividades, a economia do desagradável e do agradável é posta em dinâmica pela imitação, produzindo o efeito desejado. A brincadeira procura criar esse espaço, encerrando estas contradições, fazendo com que o sujeito seja capaz de se afirmar sobre a realidade, na medida que ela, também, o condiciona: 
Lembremos ainda que o jogo e a imitação artísticos dos adultos, que, diferentemente do que fazem as crianças, dirigem-se à pessoa do espectador, não poupam a este as mais dolorosas impressões - na tragédia, por exemplo -, e, no entanto, são por eles percebidos como elevada fruição (FREUD, 2010, p.175).

Além do princípio do prazer pode ser visto, talvez, como o texto mais interessante de Freud para se pensar o autômato, devido à recorrência de temas relacionados à infância e ao brinquedo. Não por acaso, é o texto sugerido no estudo do caso da boneca. A participação da boneca Olímpia em "O inquietante" toma, assim, um novo significado. Sobre estas questões, oito anos depois, Walter Benjamin vai compor uma bela imagem, em "Brinquedo e brincadeira: observações sobre uma obra monumental", relacionando brinquedo, brincadeira e atividade sexual:

Sabemos que a repetição é para a criança a essência da brincadeira, que nada lhe dá tanto prazer como "brincar outra vez". A obscura compulsão de repetição não é menos violenta nem menos astuta na brincadeira que no sexo. Não é por acaso que Freud acredita ter descoberto nesse impulso um "além do princípio do prazer". Com efeito, toda experiência profunda deseja, insaciavelmente, até o fim de todas as coisas, repetição e retorno, restauração de uma situação original, que foi seu ponto de partida (BENJAMIN, 1984, p.253).

A imitação, conforme Freud a concebeu, opera à nível de encenação. Benjamin entende essa atitude de representação como a transformação em hábito de uma experiência devastadora, na qual o brinquedo é o elemento externo, que vem a ser apropriado 
pela criança na brincadeira. É nesse sentido que Freud vai afirmar que a equivalência entre brinquedo e mundo infantil é ilusória, portanto, é impossível aproximá-lo da arte pura, pensando no conceito romântico. A brincadeira (spielen) sim, é onde a criança faz criar sobre o que lhe foi imposto.

Pensemos, então, em "O homem da areia". O tema infantil se apresenta como uma inadequação, confundindo os lugares de entendimento. Nathanael é a criança infeliz e contrariada, que lança o seu impulso obscuro na repetição: "boneca de madeira gire, gire!" (HOFFMANN, 2017a, p.115). À Olímpia quebrada corresponde mais uma das repetições infinitas de uma experiência profunda, insaciável, que acaba tendo um fim trágico pelas mãos do Homem da Areia, e aí que a repetição se apresenta como uma impossibilidade. Nesse destino, incorre também Ferdinando. A esses sujeitos criar para si o fato vivido é impossível, pois são como que títeres nos fios de sujeitos sombrios, diabólicos: Spalanzani, Professor $X$, dentre outros farsantes que espreitam para que o artista, como a criança, já não saia mais vitorioso e saboreie do contato com o espírito superior da arte. A experiência da repetição desemboca, assim, naquilo que Freud chamou de inquietante.

A estrutura da repetição nas crianças é a do adulto que narra a sua história para se sentir, sobre a realidade, um pouco mais sujeito ativo. Em Hoffmann, para o projeto das suas personagens autômatos, temos um quadro social em que esta atitude não se faz mais possível. Isso porque o objeto artístico, único capaz de fazer as contas entre homem e natureza, segundo se teve como princípio no romantismo, e que Adorno atualiza com as questões do inconsciente freudiano, foi usurpado por farsantes, que, como 
Spalanzani, merecem acabar atrás das grades por ilegalidade. A leitura de Freud (2010b) sobre o inquietante latente das obras de arte, talvez, não pudesse chegar a esta questão, pois mesmo a extrapolação freudiana da estética é efetivada por ele com ressalvas. Contudo, sob à luz lançada por Adorno (1970), podemos enfim compreender que o inquietante é um texto tão polimorfo quanto o brinquedo nas mãos da criança. Assim, depois dessas reflexões, o inquietante se apresenta como o diagnóstico de Hoffmann para a experiência artística do homem na tecnocracia.

\section{REFERÊNCIAS}

ADORNO, Theodor Ludwig Wiesengrund (1970). Teoria estética. Lisboa: Ed. Martins Fontes.

BENJAMIN, Walter (1984). "Brinquedo e brincadeira". In: Reflexões: a criança, o brinquedo, a educação. Marcus Vinicius Mazzari (Trad.). São Paulo: Summus.

CESAROTTO, Oscar (1987). No olho do outro. Ricardo Henrique Ferreira (Trad.). São Paulo: Max Limonad.

FREUD, Sigmund (1996). "Três ensaios sobre a teoria da sexualidade". In:

Edição Standard brasileira das obras psicológicas completas de Sigmund Freud (1901-1905). Rio de Janeiro: Imago Editora. p.119-218.

(2010a). "Além do princípio do prazer". In: História de uma neurose infantil: "O homem dos lobos"; Além do princípio do prazer e outros textos (1917-1920). de Paulo César de Souza (Trad.). São Paulo: Companhia das Letras, p.161-240.

(2010b). "O inquietante". In: História de uma neurose infantil: "O homem dos lobos"; Além do princípio do prazer e outros textos (1917-1920). de Paulo César de Souza (Trad.). São Paulo: Companhia das Letras, p.328-277. HOFFMANN, E. T. A. (1993). "Os autômatos". In: . Contos fantásticos. Claudia Cavalcanti (Trad.). Rio de Janeiro: Imago. 
(2017a). "O homem-areia". In: . O reflexo perdido e outros contos insensatos. Maria Aparecida Barbosa (Trad.) (Org.). São Paulo: Estação Liberdade. p.76-116. (2017b). "O Quebra-nozes e o Camundongo rei". In: O reflexo perdido e outros contos insensatos. Maria Aparecida Barbosa (Trad.) (Org.). São Paulo: Estação Liberdade. p.190-256.

VOLOBUEF, Karin (1999). Frestas e arestas: a prosa de ficção do romantismo na Alemanha e no Brasil. São Paulo: Editora da UNESP. 